JOURNAL OF AWARENESS

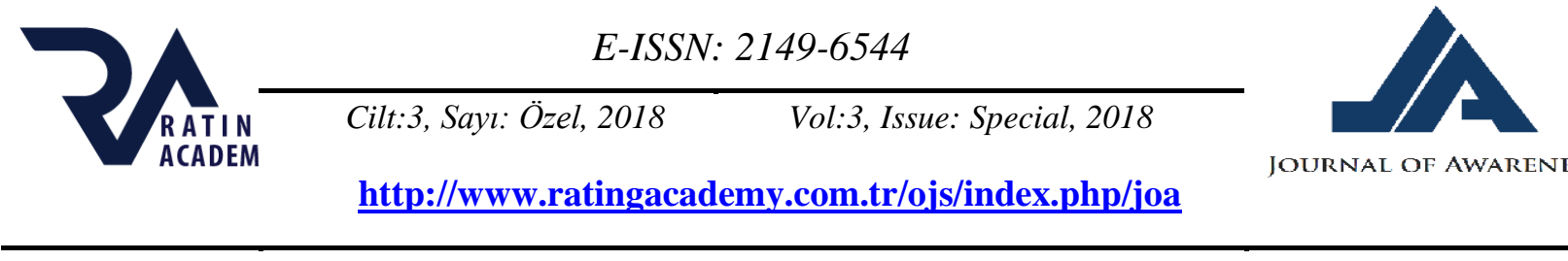

\title{
ABOUT THE HISTORY OF ESTABLISHMENT AND DEVELOPMENT OF THE FINANCIAL TERMINOLOGY IN THE AZERBAIJANI LANGUAGE*
}

\author{
Günel Feyruz QURBANOVA \\ Bakü Slavyan Universitesi, Azerbaijan \\ E-mail: suleyman.quba@mail.ru
}

\begin{abstract}
ARTICLE INFO
Keywords:

term, borrowed words, term establishing, finance, history of the terminology
\end{abstract}

\section{DOI:}

10.26809/joa.2018548653
During the study of economic terms, it has been confirmed that financial terminology in Azerbaijan and in the east has ancient history. As Azerbaijan is located in the favorable strategic position, on the trade routes, trade relations have been developed rapidly here.

The economical lexicon comprises a special, voluminous layer of lexicon. From time to time, this terminology area is subject to modifications, it is renewed, enriched through new lexical units.

The article deals with the establishment, formation and development of financial terminology in Azerbaijan. The path passed by the financial terms from the ancient times up to present is analyzed and studied. The origin, development path and current condition of the financial terms used both in daily life and in the literary works and in the media is reviewed. The role of economic and trade relations in this area is interpreted through the historical stages. New expressions and notions emerged in our language as a result of fundamental economic, social and political, cultural reforms, public and social changes that have emerged since our country gained independence have contributed to the enrichment of our vocabulary fund, especially terminology and the economic terminology of our language has grown rapidly in the last twenty years. The impact of Turkology congresses and seminars on the terminology creation process in Azerbaijan was also in the focus of attention. Great attention and care of the head of the state Mr.IlhamAliyev to the development of Azerbaijani language is specially emphasized. The economic terminological layer of our language is developed, enriched and renovated rapidly, the financial terminology is enriched by new financial terms during the present development period of our Republic and expansion of economic-political relations with the most countries of the world. Establishment of Terminology Commission in Azerbaijan is one of the most important steps in thisarea. As if, a breakthrough has happened in the terminology system of Azerbaijan Republic by the establishment of this Commission and rapid development dynamics is observed. Different terminological dictionaries are prepared and published for all fields.

It is important to state specially the role of media and textbooks in the development of terminology in Azerbaijan. It is true that there are some improvements in this area, but there are still unrevealed issues that are not yet clear in the textbooks. It shall be considered normal, as the formation of new economic relations in Azerbaijan requires the creation of new financial and banking terms. As mentioned above, it is realized either by the internal capacities of the language or words borrowed from other languages.

Especially, the rapid development of the world economy, transition to the market economy, expansion of the banking system network, enhanced economic relations with foreign countries and signed various agreements have increased the interest in this area in the recent years. Access to the world market, along with economic 
accomplishments, causes to mass word flow to the lexicon and creation of new terminological units in every language. Therefore, currently, the financial terminology is distinguished by its special role in the lexical system of the language. At the same time, the close cooperation of the vast majority of the population with the banking system has contributed to the further expansion of the scope of financial terms.

\section{TERMS}

As a new approach to the happened processes and the environment encircling us emerged in accordance with a new social-political system formed after the collapse of the Soviet epoch, a new concept has appeared in the field of terminology of the linguistics; human consciousness doesn't only reflect the reality, at the same time, it makes that reality. In the reality, this conception reflects both sides of classic philosophy. That is to say that whether the reality is reflected or established in the human consciousness. The historical reality shows that the collapse of the Soviet political system and emergence of new economic - political relations have created new concepts in almost all fields of science, especially in humanitarian fields. While some of them demanded the revision of existing terms, on the other hand, the terms emerging from new scientific concepts began to emerge. This was the manifestation of the second concept given above.

As in the most world languages, the lexical layer of the Turkiah languages is the most active place and is chosen by its instability, because factors affecting the language are primarily manifested in the lexic layer. This thesis adopted by the world linguistics is closely linked to the general development of the language and is directly related to the realization of the inner and outer effects primarily in the lexical layer (6, p.8).

It is impossible to imagine our modern day without science or technology. Their development is related to the increasing awareness regarding this field and their special expression style. More precisely, scientific concepts differ from commonly used words for their specific features and make a special group in the lexis of the language that it belongs to. They are calledterms. "Term" is a Greek word and expresses limit, border content. In the essence, terms call subject, event, feature or relation regarding any scienfitic field. But, differing fromcommonly used words, terms are specific to the vocabulary of the specialists, but, they name the scientific notions. When we compare them with the commonly used words, we shall say that the efficient turnover and speed of terms is lower than of the commonly used words. On the other hand, the semantics of terms do not depend on the context, though that they sounded separately. When the terms are formed, the phonetic, lexical, morphological and syntactic rules of the language which they belong to are fully observed. They make a relevant layer in the lexical system of the language.

There are different views on the process of internationalization of terms in the linguistics; in a group of languages terms are taken from Greek, Latin, Arabic and other languages and are used in most of the world languages and have international character. This direction is widespread In the life of the terms. In some languages, for example, in German, Czech and other languages, the process of nationalization of terms is going on. The existence of opposing processes does not deny the basic principles regarding terms. Term creativity is a linguistic event; word is the principal unit of terms. Both simple and complex structured terms are formed through them and the corresponding concepts are coded with their help. Unlike the commonly used words, termin like coding is concretized from the semantic point of view forming a lexical unit expressing the idea, they are separated from other meanings and individualized. Terminology has been formed on the basis of lexicology and its main function 
consists of the typology of terms. It includes issues such as their form, content, and function. Recently, the term "terminology" implies a total of some terms related to certain fields of science. From the 60s of the XX century, the terms "terminological lexicon", "terminolexicon" and "terminology" have been used to call all terms in the language. The term "terminology" refers to the meanings we have mentioned above in the modern linguistics.

\subsection{Cognitive aspect of the terms.}

Cognitive linguistics, cognitive terminology is considered the last achievement of the linguistics. Cognitive terminology located at the junction of several sciences is of great interest in the modern period. The main target of cognitive terminology is the principles of use of the terms in the cognition system of men. Because each term is based on exact knowledge field. The cognitive approach to the terms aims to settle both the practical and scientific theoretical issues of the terminology. The semantic approach to the terms looks like the semantic analysis of the vocabulary. However, it encircles the words that represent a specific area of human activity basing on the context of traditional analysis of ordinarylexical units. The terms are approached in two aspects in the theoretical terminology: A part of terms are regarded as the sign having emotional neutrality not depending on the monosemanticity, systematicness, isolated ideal sign, the context. Other part of terms are regarded from the functional point of view. The supporters of this point of view regard the term from the point of view of use in the text and the function. The semantic analysis of this field of science does not cover only the requirements of modern linguistics, so the cognitive approach to the issue appears as a necessity.

Protection of knowledge in the brain, its use and presentation is realized on the basis of certain cognitive models. The first part of the issue is related to the frame character of terms. As we know, the frame is the structural unit of the concept. If we use the word "family" as a sociological term, then we create a new meaning of this vocabulary unit (terminological meaning), and from a cognitive point of view, we formulate a new frame of the concept of "family." The definition event occurs here. Definition means separation, more precisely, the concretization process separating from other meanings. For example, the term "family" means such a semantics like as "spouse", "union of one generation" as a lexical unit. However, when it is used in the semantics such as "society" and "social organization", it is separated from the previous meaning and makes a new meaning - a frame is formed. Consequently, the definition occurs and enrichment takes place in its semantic structure. The terms formed as a result of the definitions are the reuse of those words in human consciousness. Re-use is a complex mental process carried out in the knowledge base of every human being.

\section{CREATION AND DEVELOPMENT OF FINANCIAL TERMS IN AZERBAIJAN.}

As in some field terms, the history of creation of our language's financial terminology dates back to the ancient times. The enrichment of this field vocabulary up to the modern level is directly related with the economic lifestyle of the people and the formation of the national thinking.

Linguists who have made researches on the enrichment of the vocabulary of Azerbaijani language have divided the history of language enrichment into three stages:

1. The period of formation and development of the Azerbaijani literary language on the basis of the national language (from VII-VIII centuries to the 20s years of the XIX century);

2. The period of stabilization of the Azerbaijani literary language on the national language (from the 20s years of the XIX century to the 20s years of the XX century); 
3. The post-Soviet era in Azerbaijan (from 20-30s years of the XX century up to the presen time) (7, p. 45).

Linguists dealing with this field use the Soviet phase as the most productive period of the vocabulary and the post-economic, political, and cultural approach that began with Russia from the XIX century. Looking at the history of our language, we can confidently say that the vocabulary of our language has been enriched and developed with new words at every stage. It is possible to observe this process in the formation of economic terms. Looking at the branches of the epos "Kitabi - Dede - Gorgud", an ancient written monument of the Turkish peoples, we can meet numerous expressions about financial issues here. The information given in "DadaGorqud" epos confirms that, along with natural exchange in the life of the Azerbaijani oghuzes, money plays a certain role and is used as means of circulation and collecting money. In the Epos, such terms as copper, silver, gold coins, their distribution, treasure and others are mentioned in the branches. "Keçənindənotuzüçaqçaalurd1, keçməyənindəndögədögəqırqaqçaalurd1..." (D-1553). "Kafirdəxidüşübənbiryerdəaqçaülüşməkdəydi". (D-723). There are such expressions as "a lot of money", "distribution of money", "gold - silver coin", "gold", "less silver" and so on in the branches. Generally, the financial officers were called as the imgha (or umgha) in Oghuz Turks. This indicates that at that time, the issue of taxation directly related to the financial concept was of great importance. certain types of taxes are not mentioned in KDG. However, in the historical literature that deals with those times various types of taxes are mentioned. The land tax takes one of the important places. This tax is managed by tribute, natural or money and is paid by the so-called "soul" tax (jizya tax). The divan tax was called the "feee", the costs of military defense and attacks were derived from the wealth accumulated in the treasury (5).

We can also observe the fact that the financial terms have ancient history in the verses of the Holy Quran, the Holy Quran. In the Holy Quran, verses related to money circulation are shown, such financial terms as "mülk, seçim, borc, sərmayə, xüms, zəkat, fitrə, cizyə, üşr (land tax)" are stated there. It is said that money is the most nasty, disgusting and ugly action. "Allah sələmiməhvedir, sədəqələriisəartırır" (Al-Baqarah verse 276). (4, p.109).

On the other hand, trading by Hazrat Mahdi (s.a.s) from his youth to the time of Prophecy indicates the ancient history of this field and its terminology.

According to the historical sources and works by N. Ganjavi, there were many types of taxes at that time - in the XII century. It is enough to note that only in the Atabeyler period (1136-1225), the amount of the annual tax of the province of Azerbaijan was 8.57 million abbasis dinars and 3 million dinars from Aran and Mughan provinces were included in the treasury of Atabeyler. (8, p. 68)As the history progresses, the rapid development of trade relations and coverage of wider geographical areas are not limited to the occurrence of financial statements and it creates the basis for scientific works to be made. The great Azerbaijani thinker NasreddinTusi who lived in the XIII century had valuable ideas and thoughts in the area of economic theoretical knowledge along with other fields of science. His work“"Oxlaqi-Nasiri” and "Maliyyəhaqqindatraktatı" (The Tract on Finance) devoted to the analysis of economic issues indicate the ancient history of the financial terms (4, p.110).

Since the middle of the XIX century, many terms gaining economic meaning have been replaced by new words and terms relevant to the period. Up to that time, currency units such əşrəfi, axça, para, on q1zıl, əskinaz, beşgümüştumən, şahı, abbası were replacced by new terms such as qəpik, manat, təklik, üçlük, beşlik, onluq, yüzlük and so on. Some of the economic terms used in this period in regard to the sales and purchase relationships are still kept in the dialects and accents: arşın, kirvənkə, pud, batman, misqal and so on. 
It shall be noted that at each stage, the occurrence of terms relating to different economic fields shall be considered acceptable. For example, though that the terminology related to agriculture and silk was widespread in the XIV century, since the second half of the XIX century, many terms for our language related to the creation of capitalist relationships, production areas, commercial enterprises and syndicates have occurred: sindikat, sənayekapitalı, aksionerkampaniyası, bankir, kapital, firma and so on.

In the second half of the XIX century, it is necessary to pay attention to the work done by "Ekinchi" newspaper and its publisher, educator H.Zardaby, who is considered to be a progressive press representative of the period in order to obtain detailed information on the terminology of the Azerbaijani language.

The publication of the newspaper "Ekinchi" starts a new stage in the formation of economic terms in the Azerbaijani language. In the printed edition, besides the terms regarding trade, industry, banking and finance, a number of new terms of economics have also been developed. We read from number 21 dated November 6, 1876 : "The newspaper MoskovskiVedomostiwrites that the next year, the vizier is reluctant to make cut some money: 19 million five hundred manats imperial, 9 hundred thousand gold of 3 manat, 6 million and five hundred thousand silver manats and 7 hundred thousand black which 50 manat of which is pood $(3$, p. 233)

In addition to the above mentioned terms, the newspaper also has a number of other terms:bankir, bankinot, gömrük, tamojnı, gömrükxana, aksızxərc, gömrükrüsumu, baqqal, sövdəgər, bəzzaz, sələmçi and so on.

Speaking of new terms emerged during this period of the literary language, it is necessary to mention the activities of the outstanding play-writer, philosopher, educator M.F.Akhundov in this period. The works of M.F.Akhundov played a great role in the creation of new terms in Azerbaijani, the introduction of terms in other languages and in enrichment of the vocabulary of our literary language in general. In his comedies, philosophical letters and works, M.F.Akhundov used Arabic, Persian, and Russian-European terms: mədaxil, məxaric, sərmayə, dərəceyi - izafi, daxod, ekonomiya, proqres, svilizasiyon, rüsum, sənaye, perevorot and so on. (1)

The dictionaries adopted by the prof. MirzaKazımbey and S.M.Ganiyev have played a great role in finding the corresponding equivalents in the Azerbaijani language for many economic terms used in the Russian language in the XIX century, as well as in the definition of their meanings, as well as many words related to the folk language. .

Although the formation of the terminology in Azerbaijan dates back to the VI-VII centuries, its development period dates back to the beginning of the $\mathrm{XX}$ century. At the beginning of the XX century certain changes took place in the economic life of Azerbaijan.

By the beginning of the XX century, the origin of the terms was Arabic, Persian, and partly Russian and European. Their business circle was not as active as it is today depending on socio-political life and historical conditions. This situation covered the languages of many Turkish speaking peoples in the Soviet Union. After the Bolsheviks Revolution (1917), a new socio-political structure emerged in the vast geographical area and in this region called the Soviet Union, science and education began a new era of development and this global development seriously affected the development of various languages, including the terminology of the Turkish languages. Taking into consideration the demands of those years, a special body - the Terminology Commission attached to the Board of People's Commissars of Azerbaijan was organized for the establishment of the scientific language in Azerbaijan Republic, the creation of textbooks for teaching and the management of terminology and for 
the development of literary language on the initiative of N.Narimanov and S.Aghamalioghlu. TaghiShahbaziwas appointedas the Chairman of the Commission "(9). During this period serious problems appeared in terms of terminology. One of them was an attempt to create terms based on the internal capabilities of the Azerbaijani language. Because at that time many Arabic-Persian terms were used in the language so that the need of preparation of special dictionaries for understanding them was clear. The Terminology Commission attached to the Board of People's Commissars of Azerbaijan was organized for adjusting them and carrying out the terms policy in the language purposefully. TaghiShahbaziwas appointed as the Chairman of the Commission. In 1923 the Terminology Commission was transferred to the Central Executive Committee of Azerbaijan. At the same time, the goal was to keep control of the work done in regard to the terms. Because the Purists took a more radical position and put forward the fact that all the terms were of Azerbaijani-Turkish origin. Of course, these principles also had defective sides either.

Terminological processes in modern sciences have proven that the process of internationalization in terms is already a reality and it cannot be denied. At that time, the press has a special role in the development of terminology. For example, in 1923, "the Communist" newspaper published a special leaflet entitled "The Term of Our Language" once a week. This indicates that the terminological movement in Azerbaijan was carried out on a large scale. The development of the terminology in the Turkish world, as well as in Azerbaijan, is related to the name of the 1st All-Union Turkological Congress held in 1926. One of the seven issues in the congress was devoted to terminology. The report of H.B.Zeynalli on the "system of scientific terminology of Turkish Languages" was a typical program and its main content was based on the principles of creating scientific and technical terms in Turkish and in other languages and borrowing terms from other languages. However, despite the seriousness of these issues at the congress, although its general principles were tried to be clarified, the development of the Azerbaijani language terminology could not be accurately defined. Therefore, in 1928, the Head Office of Scientific Institutions attached to Azerbaijani Public Education Commissariat was set up and terminology issues were assigned to that office. Later, in the early 1930s, it was transferred to the Azerbaijan State Scientific Research Institute, where works on the identification of scientific principles for the development of terminology and the development of the spelling dictionary were started. Preparation of the spelling dictionaries was also assigned to the terminology department. In 1944, the Azerbaijan Terminology Committee was transferred to the Council of People's Commissars of Azerbaijan. The main purpose was to seriously monitor the preparation of terminological dictionaries and to prevent mistakes in this area. After the publication of the dictionary "Philosophical Terms", it was sharply criticized at the XIII Congress of the Azerbaijan Communist Party. "In 1948, by the decision of the CentralCommittee of the Communist Party of Azerbaijan, in order to regulate establishment of terminology in Azerbaijan language, to prevent the disorder in this field, to supervise the terminological activities conducted in scientific-research institutions and higher schools, the Terminology Committee under the Presidium of the Academy of Sciences of the Azerbaijan SSR was established. In that year a conference was held in the Academy of Sciences together with the Central Committee of Azerbaijan to determine the functions of the Terminology Committee. The language conferences convened in Baku also played a role in the regulation of terminology. In the report of Professor M.S.Shiraliev, the borrowing of foreign words without the need for terminology was criticized as a malicious principle that we need to clean out foreign words that are not in the spirit of the Azerbaijani language without any need (9). More than 200 terminological dictionaries have been developed in these years covering various fields of science. In 1969 the Terminology sector was established in the Academy of Literature and Language of the Azerbaijan SSR. In 2000, Terminology Committee under the Presidium of ANAS was renamed as the Terminology Commission. Structural improvement in terminology, 
as an integral part of state language policy, has yielded results; significant achievements have been achieved in this field. Nevertheless, since the Azerbaijan language acquired the status of the state language, it was required to look at a number of terminological issues from the new prism. Taking this into account, on May 29, 2012, the Terminology Commission under the Cabinet of Ministers of the Republic of Azerbaijan was established to regulate and co-ordinate activities in the field of establishment of terminology in Azerbaijan language. On November 26, the Regulations of the Commission were approved. The seminars held in Turkic Republics have a great role in the development of terminology in Azerbaijan. For example, on September 5, 2013, the Turkic Council with the organization of the Terminology Committee has held a seminar on Terminology Issues - the process of terminology establishment in Turkic Academy established in Kazakhstan. The seminar discussed the current state and future development of terminology in Turkish-speaking countries (9).

Discussion of terminological issues in mass media in Azerbaijan has given its positive yield.

This institution starting to act as the Correction Commission under the Council of People's Commissars of Azerbaijan now acts as the Terminology Commission under the Presidium of the ANAS. This organization has supervised many of the published dictionaries related to terms, and has achieved excellent publishing. The first terminology dictionary is also related to the period in which the Terminology Commission of Azerbaijan was created and according to experts, this commission has produced and published more than 300 dictionaries. Beginning from the second half of the twentieth century, the circulation and volume of scientific concepts began to increase, which is reflected in the development of terminology science.

On May 23, 2012, an order was issued to establish a Terminology Commission under the Cabinet of Ministers of the Republic of Azerbaijan and on November 26, the Regulations on the Terminology Commission under the Cabinet of Ministers of the Republic of Azerbaijan have been approved (10). The Regulations consist of four parts. The first part is called General Provisions, and the main goals and objectives of the establishment are given here as follows: "1.1. Terminology Commission under the Cabinet of Ministers of the Republic of Azerbaijan (hereinafter referred to as the Commission), established in accordance with the Order of the President of the Republic of Azerbaijan dated 23 May 2012 № 2236 “On the State Program on the use of Azerbaijan language in accordance with requirements of the in the condition of globalization and development of linguistics in the Country" implements the functions of regulation and coordination of work in the field of term establishment, as well as enrichment of the language content, determination of the possibility of using new literary concepts and expressions in the language, control of the use of new terms and definitions in accordance with language norms in mass media, textbooks and other teaching aids to improve the literary language performs its functions" (10).

Rapid development of science and technology in the world recently, emergence of new scientific fields and development of terminology, enrichment of terminological bases, and the increase of terminological centers in the world and in Azerbaijan have revealed the need to create a terminological information system for their single-base management.

"The State Program on the use of Azerbaijani language in accordance with the requirements of time in the conditions of globalization and the linguistic development in the country, approved by the Order of AR President IlhamAliyev dated April 9, 2013, set forth important tasks in front of the relevant institutions. In connection with the provisions related to the application of information and communication technologies (ICT) in the field of study and propaganda of Azerbaijani language, purposeful work was also carried out at the Institute of 
Information Technologies of ANAS, the concept and web portal of the National Terminology Information System has been developed by the scientists and experts of the İnstitute" (11).

The existence of different languages in the world and the incompatibility of the terms in them reveal the necessity of standardization at the international level. The existence of thissystem determines the exact interpretation and definitions of terms. It covers the following issues:

$"$ - determination of the standard on terms and the determination of the current level of scientific knowledge and technical development; - Harmonization of scientific and technical terminology at national and international levels; - ensuring mutual development of agreed lexical means used in information systems; - Detection and elimination of deficiencies of terminological lexis used in literature and documents "(12).

In modern times, terminology needs to be approached from the point of view of information and communication technologies. The globalization process in the world also affects the language, including terminology. Therefore, serious measures are being taken by the state to protect the languages in the world. Implementation of state measures in the field of language application and protection is appearance of the state support to the language. Orders that follow one another are essential for the purity, comprehensive development of our language, and the wide range of possibilities in the period of computer technology.

"Thus, the current situation in the field of terminology in Azerbaijan, the problems that are based on objective and subjective factors in this field, the state care for language protection and development, expansion of information and communication technologies capabilities and penetration in all fields, on the other hand, establishment of a number of international centers, development of international standards in this field, creation of terminological banks, databases and so on reveal the development perspectives of the terminological activity and necessitate the development of a new information model of terminology activity in Azerbaijan - a terminological information system" (12).

At the Institute of Linguistics named after Nasimi of ANAS, terminology department has been established and soon enough scientific products have been created. The following are examples of them: "Fundamentals of the Azerbaijani language terminology", "Dictionary of clerical and accounting terminology", "Dictionary of terms on remote sensing of earth", "Bibliography of literature and dictionaries on terminology of Azerbaijani language" 1. M. Sadigov, T.Pashayev ,M.Gasimov. Financial Credit Terms Dictionary.

While economic terminology, including financial terms, was derived from works by English economists in the XVII-XIX centuries, and from the XX century they addressed to the works of American economists and the term establishment in them. Greater British andAmerican economists have a great role in the development of modern economic terminology. Mass media, textbooks play a great role in the development of terminology in Azerbaijan. Of course, there are some progresses in this field, but there are still issues that are not yet clear in the textbooks. It is also necessary to approach it in normal manner, as the formation of new economic relations in Azerbaijan requires creation of new financial and banking terms. As we have explained above, this is done either through domestic or foreign language borrowings. Of course, certain difficulties on the way lead to some shortcomings in the terminology. For example: In our economists' opinion, there are still some "marketing" terms in English that can be translated into Azerbaijani. In this regard, it is said: "There are a number of terms in Azerbaijan language that has been taken from English today, which, according to some economists, can be accepted through translation. For example, "marketing" - market means bazaar. English suffix is added; "Management" - consists of "manus" which means hand in Latin and "ment" suffix. We want to show the possibilities to translate these 
words and expression of them in Azerbaijan and other languages with new terms by giving the definition of them in two encyclopedic dictionaries: marketing (English marketing) - a system of measures on market study and active influence to consumer demand: the development of new types of products, management and organization of production and sales or services: management (English management) - principles, methods, means and forms of intellectual finance and other resources management of production volumes; management practices and the theory of production and sales aimed at increasing its efficiency and increasing profits (13).

An important issue related to eliminating difficulties connected with financial terminology is the creation of a dictionary fund that covers all economic terms. As a result, terminological dictionaries are prepared. In the modern era of translation practice, the translation requires that the translated text should be closer to the original. The term to be translated must be unambiguous and clear regardless of context.

In general, the development of economic terminology opens up opportunities for the development of economy science.

\subsection{Impact of international terminological centers on terminological movement in Azerbaijan.}

The formation of terms and improvement of their content is closely linked to the emergence of terminological centers around the world. The subsequent and logically complementary international terminological organizations have played a crucial role in the correct and timely resolution of important issues in this field. Some of these organizations have emerged dependent on the needs of the period in this field. Aliguliyev R.M. and GurbanovaA.Mexpressed the growth dynamics of the international terminology organizations as follows: "The first Terminology Center in the world was founded in Viezbelburg (Austria) in the 30s of the last century, and the founder of the general terminology theory, EygenWyuster, was the head of this center. The Terminology Center has been involved with the UNESCO and other international organizations' projects and has contacted world-renowned experts in this area. E.Wyuster founded the Secretariat of Terminology (Principles and Coordination) of the International Organization for Standardization in 1951. At present, this center is a part of the Scientific Theory Archieves of the University of Vienna. In 1971, the UNESCO and the International Committee for Scientific Affairs held a conference of the countries where the project of creation of the International Science Information System (World Science Information System) was announced. This project, led by E.Wyuster, is a multilingual terminology system that uses standardized terms. That year, International Information Center for Terminology Infoterm (International Information Terminology) has been established. Infoterm that has been established in order to coordinate and support cooperation in the field of terminology in the world organizes workshops on language and implements important projects and programs in the field of terminology beginning from 1977. Infoterm promotes and supports the idea of creating new terminological centers and networks in order to deliver knowledge and information in a global multilingual society. In 1976, Infoterm was involved in a research called "Development of Terminology in Network" and as a resultTermNet (International Terminology Network) was organized. TermNetwas registered as a nonprofit organization in 1988. This network currently has more than 40 members. "Conceptual Basis for the Establishment of Azerbaijani Terminology Information System” (14).

Establishment of terminology banks and their use by terminological banks of various countries (EURONET), creation of terminological database is a logical consequence of the above mentioned works. The XX-XXI century is a period of great development of science and technology. Accordingly, the rate of growth of new scientific concepts is accelerating from day to day and ways of their formation are further developed. 


\section{BIBLIOGRAPHY}

1. Axundov M.F Osərləri II cilddə, I cild. Bak1, 1988.

2. “Azərbaycanterminolojiİnformasiyasistemininyaradılmasınınkonseptualəsasları”, 2012.

3. "Okinçi”" qəzeti. Bakı, 1979.

4. İqtisaditəlimlərtarixi. Bak1, 2005.

5. "Kitabi - DədəQorqud” ensiklopediyası, 2012.

6. Qasımov İ. MüasirAzərbaycandilindəhərbiterminlərinyaranmayolları. Bakı, 2000.

7. Qasımov M. Azərbaycandiliterminologiyasınınəsasları. Bakı, Elm, 1973.

8. Vəliyev T., Həsənov A. Azərbaycaniqtisadifikirtarixi. Bak1, 1996.

\section{Electron resources:}

9. (www.azerbaijan-news.az/index.php? $\bmod =3 \& i d=31234)$.

10. (www.cabmin.gov az//az/ pressreliz/view/836/).

11. (MilliTerminolojiİnformasiyaSistemininkonsepsiyasıNoy 25, 2016 17:18 / Konfranslar, İclaslar).

12. (library.ict.az/elektron2015/6.pdf).

13. (http:xalq qazeti.com/az /news/ news/ 70008).

14. jpis.az/ storage//f264785ddd1 403f86445b8b1e358820a.pd). 